\title{
Assessment of Irrigation Water Quality in Menzel Habib Aquifer System - A Combined Geochemical and Fuzzy Logic Approaches
}

Oussama Dhaoui ( $D$ oussama.dhaoui@enis.tn )

Universite de Gabes Institut Superieur des Sciences Humaines de Medenine

\section{Belgacem Agoubi}

Higher Institute of Water Sciences and Techniques of Gabès

\section{IMHR Antunes}

Institute of Earth Sciences, Pole of University of Minho

Lotfi Tlig

Higher Institute of Informatics and Multimedia of Gabès

Adel Kharroubi

Higher Institute of Water Sciences and Techniques of Gabès

\section{Research Article}

Keywords: Groundwater, quality indices, fuzzy logic, agricultural use, Tunisia.

Posted Date: October 26th, 2021

DOI: https://doi.org/10.21203/rs.3.rs-931969/v1

License: (9) This work is licensed under a Creative Commons Attribution 4.0 International License. Read Full License 
1 Assessment of irrigation water quality in Menzel Habib aquifer system - a combined geochemical and Fuzzy logic approaches

\section{Oussama Dhaoui ${ }^{1 *}$, Belgacem Agoubi ${ }^{1}$, IMHR Antunes $^{2}$, Lotfi Tlig $^{3}$, Adel Kharroubi ${ }^{1}$}

${ }^{1}$ Higher Institute of Water Sciences and Techniques, University of Gabes, University Campus, 6033 Gabes Applied -Hydrosciences Laboratory.

${ }^{2}$ Institute of Earth Sciences, Pole of University of Minho, Campus de Gualtar, 4710-057 Braga, Portugal

${ }^{3}$ Higher Institute of Informatics and Multimedia of Gabes. University Campus, 6033 City El Amel 4, Gabes, Tunisia

\section{*Corresponding author: oussama.dhaoui@enis.tn}

\section{Abstract}

Groundwater is an important source for irrigation uses in many arid and semi-arid regions such as Menzel Habib area. In this work, the groundwater quality for irrigation water was investigated based on conventional indices notably Electrical Conductivity (EC), Sodium Absorption Ratio (SAR), Soluble Sodium Percentage (SSP), Magnesium Adsorption ratio (MAR), Kelly Ratio (KR) and Permeability index (PI). The water quality for irrigation was also evaluated by Simsek method. However, a proposal fuzzy logic model has been developed to avoid uncertainties associated to the classical methods. The results obtained on thirty-six groundwater samples, indicated that $3 \%$ of these samples are classified as "good" for irrigation, 3\% are "good to permissible", 33\% "permissible", 36\% "permissible to unsuitable" and $25 \%$ with an "unsuitable" quality. The application of fuzzy logic approaches has more 
reliable results with the definition of seven classes to evaluate the groundwater quality for agricultural irrigation.

Keywords Groundwater . quality indices . fuzzy logic . agricultural use . Tunisia.

\section{Introduction}

Water scarcity is a global issue of concern that affects all socioeconomic activities and threatens the sustainability of the natural resources. The development of agricultural lands, to provide food for the growing population, highly depends on the availability of irrigation water (Ghazaryan et al. 2020). Indeed, agriculture has become the main sector of water consumption (Kawo and Karuppannan 2018).

The consumption of low-quality water can promote serious diseases in the population, permanent damage to the ecosystem and economic losses (Schwarzenbach et al. 2010). Especially for countries located in arid and semi-arid climate zone, efficient management of water resources is crucial to prevent economic losses. Therefore, the sustainability of water resources is directly related to water quality protection (Kavurmacı and Karakuş 2020).

Groundwater is an important source of irrigation water all over the world, as well as in arid and semi-arid areas. Groundwater quality depends on various factors, natural and/or anthropogenic, such as hydrogeology, degree of mineral weathering, ion exchanges, evaporation, groundwater flow and human activities (e.g., Agoubi et al. 2012; Alabjah et al. 2018; Isawi et al. 2016; Kharroubi et al. 2012 Telahigue et al. 2018), as well as by climate change (e.g., Burri et al. 2019; D'Alessandro et al. 2020; Hu et al. 2019).

Evaluation of groundwater quality is an important tool to promote sustainable development of agricultural areas and to provide important water management data (Kavurmacı and Karakuş 2020). Therefore, it is useful to provide information on water quality, classification of water 
for various purposes, assessment of groundwater potential, and investigation of different chemical processes (Al Maliki et al. 2020).

Numerous studies on water quality assessment have been developed with different techniques to evaluate water quality, essentially based on chemical relations, physical proprieties, and Water Quality Index (WQI) (e.g., Abd El-Aziz, 2017; Al Maliki et al. 2020; Ben Alaya et al. 2013; Ghazaryan et al. 2020; Pazand and Javanshir 2014; Prasad et al. 2019; Tian and Wu 2019). Different hydrochemical indices, such as Sodium Adsorption Ratio (SAR), Sodium percentage $(\mathrm{Na} \%)$, Magnesium Hazard $(\mathrm{MH})$, Residual Sodium Carbonate (RSC) and Permeability Index (PI) are applied to the assessment of groundwater quality for agricultural irrigation (Ghazarhyan et al. 2020; Beyene et al. 2019; Mirza et al. 2017; Safiur et al. 2017; Khan et al. 2015). Additionally, several studies used geostatistical approaches to investigate the suitability of water for irrigation purposes (El Bilali and Taleb 2020; Ghazarhyan et al. 2020; Jahin et al. 2020; Kavurmacı and Karakuş 2020; Sutadian et al. 2017).

The Irrigation Water Quality (IWQ) can be assessed by the combination of several parameters which are associated to specific irrigation concerns, such is: (i) salinity hazard, (ii) infiltration or permeability hazard, (iii) specific ion toxicity, and (iv) miscellaneous effects to sensitive crops (Simsek and Gunduz 2007). The IWQ method classifies the quality of water for irrigation into low, medium, or high suitability. Furthermore, the conventional hydrochemical and statistical approaches follow the Boolean logic which exact values will define the limits (boundaries) between different classification groups. So according to this, the traditional water quality indices values vary between 0 or 1 (e.g., good or bad), and consequently, for the same water sample, different water quality classes could be attributed with the application of previous indices; resulting an ambiguity for water quality classification (Icaga 2007).

To overcome the subjectivity and to incorporate environmental uncertainty in groundwater quality evaluation process, the application of Artificial Intelligence (AI) based computational 
methods are highly recommended (e.g., Agoubi et al. 2018; Jha et al. 2020; Lu and Ma 2020; Meyers et al. 2017; Nadiri et al. 2019; Nadiri et al. 2017; Rajaee et al. 2019). Among various computational AI methods, Fuzzy Logic (FL) is extensively used to deal with complex waterrelated environmental problems (Agoubi et al. 2016; Jha et al. 2020; McKone and Deshpande 2005; Tafreshi et al. 2018), owing to its capability to deal with non-linearity and uncertainty of environmental systems (Tirupathi et al. 2019). In addition to this, FL serves as an effective tool for conveying the results to the public and beneficiaries in a much understandable linguistic format ( $\mathrm{Li}$ et al. 2018). Nowadays, FL is extensively applied to groundwater quality assessment for different purposes and adequate management, usually combined with GIS and geostatiscal tools (e.g., Jha et al. 2020; Ostovari et al. 2014; Pathak and Bhandary 2020; Shwetank et al. 2019).

Tunisia is facing the problem of water scarcity due to its arid and semi-arid climate. This region has a rather unstable climate with irregular rainfall quantity and spatial distribution leading to either periods of drought or intensive rainy periods which makes the groundwater resources quite fragile. The Menzel Habib region (southeastern Tunisia), is well known by groundwater potentiality and quality, and is mainly used to domestic purposes and agricultural activities. So, the assessment of groundwater quality is crucial for a sustainable and groundwater management in this region.

The main topic of this study is groundwater quality assessment from Menzel Habib aquifer system for irrigation purposes and includes the following objectives: i) application of different water quality indices; ii) application of Simsek method; iii) Comparison with Irrigation Water Quality Index (FIWQI) determined by Fuzzy Logic.

\section{Materials and methods}

\subsection{Menzel Habib aquifer system}


Menzel Habib aquifer system is located in southeastern Tunisia, between latitudes $34^{\circ}$ and $34^{\circ} 20^{\prime} \mathrm{N}$, and longitudes $9^{\circ} 15^{\prime}$ and $9^{\circ} 58^{\prime} \mathrm{E}$ (Fig. 1a). The area is characterized by an arid climate and a complex geology, including formations from Triassic to Quaternary age. The aquifer system contains three different layers: the shallow aquifer is contained in plioquaternary sandy-loam formation, with a depth varying from $10 \mathrm{~m}$ to $65 \mathrm{~m}$, the Senonian aquifer, corresponding to the first deep aquifer, is logged in marl levels with limestone layer, and, finally, the Cenomanian-Turonian aquifer is in the limestone and marl-limestone formation (Fig. 1b, c).

Groundwater from Menzel Habib aquifer system is intended to agricultural activities and is mainly extracted from the shallow and Senonian aquifers because of the high salinity in the Cenomanian-Turonian groundwater level (Ben Cheikh et al. 2013). In this study, the groundwater quality assessment from shallow and the Senonian aquifers will be presented.

A total of thirty-six representative groundwater samples were extracted from the shallow aquifer (25 samples: P1 to P25) and deep aquifer (11 samples: G1 to G11) of Menzel Habib aquifer system, from water supply boreholes used for agricultural purposes (Fig. 1b). After a minimum of 15 minutes of pumping the boreholes, groundwater samples were collected and stored in polyethylene bottles. Immediately after sampling, Electrical Conductivity (EC), Total Dissolved Solids (TDS) and $\mathrm{pH}$ were measured "in situ" with a multi-parameter analyzer reference (C933 Multi-Parameter). Groundwater bottles were correctly conditioned and transported to the laboratory. On the laboratory, the water samples were filtered with a $0.45 \mu \mathrm{m}$ Millipore filter and bicarbonate $\left(\mathrm{HCO}_{3}\right)$ water content was determined through the titration method with hydrochloric acid. Selected major cations ( $\mathrm{Na}, \mathrm{K}, \mathrm{Ca}, \mathrm{Mg})$ and anions $\left(\mathrm{F}, \mathrm{Cl}, \mathrm{Br}, \mathrm{SO}_{4}\right.$ ) water contents were determined by ionic liquid chromatography Metrohm 850 Professional IC. The chemical data quality was checked through careful standardization; the ionic charge balance of each sample was within $\pm 5 \%$ error. All the determinations were 
obtained at the Integrated Laboratory of Water Sciences, Higher Institute of Water Sciences and Techniques of Gabès (Tunisia).

\subsection{Irrigation water quality parameters}

Different and combined Irrigation Water Quality Indices (IWQI) to groundwater quality assessment for irrigation purposes were applied on the Menzel Habib aquifer system. The assessment of water quality for irrigation purposes is conditioned by several parameters and indices that are fixed by many organizations and agencies. In this research, Electrical Conductivity (EC), Sodium Adsorption Ratio (SAR), Soluble Sodium Percentage (SSP), Magnesium Adsorption Ratio (MAR), Permeability index (PI) and Kelly Ratio (KR) were considered. Indeed, groundwater salinity hazard is an important quality indicator for agricultural irrigation, as high salinization renders the soil saline that affects the salt intake capacity of the crops through the roots (El Bilali and Taleb 2020).

Water salinity is generally evaluated using EC $(\mu \mathrm{S} / \mathrm{cm})$ or TDS $(\mathrm{mg} / \mathrm{L})$, according to the FAO guidelines (Ayers and Westcot 1994). In a water with TDS $<400 \mathrm{mg} / \mathrm{L}$ there is no restriction in the respective application, while if TDS varies from $400-2000 \mathrm{mg} / \mathrm{L}$ there is a slight to moderate restriction and a water TDS $>2000 \mathrm{mg} / \mathrm{L}$, the degree of restriction will be severe. For sodium hazard assessment, there are several parameters commonly applied in the evaluation of the suitability of water for irrigation purposes, such are SAR and SSP (El Bilali and Taleb 2020).

The SAR index is obtained by Equation [1]. The high SAR value degrades soil texture by reducing the hydraulic conductivity and, therefore it decreases the irrigation performance. However, water is considered unsuitable when the SAR is higher than 10, according to FAO 
145 guidelines (Bilali and Taleb 2020). The indices SSP, MAR, PR and KR are presenting on the equations [2] to [4].

147 Sodium Adsorption Ratio (SAR) is computed using equation (Richards 1954):

$$
S A R=\frac{N a}{\sqrt{\frac{C a+M g}{2}}}
$$

Soluble Sodium Percentage (SSP) is calculated according to equation (Kopittke et al. 2006):

$$
S S P=\frac{N a}{C a+M g+N a} \times 100
$$

Magnesium Adsorption Ratio (MAR) or Magnesium Hazard is calculated according to equation (Raghunath 1990):

$$
M A R=\frac{M g}{C a+M g}
$$

154 155

One of the main purposes of this study is to develop a groundwater quality index to be applied 163

$$
P I=\frac{\mathrm{Na}+\sqrt{\mathrm{HCO}_{3}}}{\mathrm{Ca}+\mathrm{Mg}+\mathrm{Na}} \times 100
$$

While Kelly Ratio (KR) is obtained using equation (Kelly 1963):

$$
K R=\frac{N a}{C a+M g}
$$

\begin{abstract}
All ion contents were expressed in meq/L.
\end{abstract}

\section{Irrigation Water Quality Index}

$$
\text { on agricultural irrigation. The water quality index is a system that could incorporate different }
$$


parameters of a water source as a single number and was firstly developed by Horton (1965). There are different water quality indexes developed with distinct methods and selected parameters (Kavurmacı and Karakuş 2020).

The IWQI is calculated by the linear combination of four groups of water quality parameters adapted from the IWQ developed by Simsek and Gunduz (2007). This index is assessed to determine the suitability of the water for irrigation and classifies the water quality into low, medium, or high suitability for irrigation. The first group is the salinity hazard which will be represented by groundwater electrical conductivity (EC) (Table 1). The second group corresponds to infiltration and permeability hazard which is determined using a combination between EC and SAR as a single parameter (Table 2). In the third group, water chloride content and SAR are used to quantify the specific ion toxicity (Table 1). Finally, the fourth group is represented by miscellaneous effects to sensitive crops based on bicarbonate $\left(\mathrm{HCO}_{3}{ }^{-}\right)$ water content and $\mathrm{pH}$ values (Table 1). All these groups are assigned by weights from the highest (4) to the lowest (1) according to the relevance of the group on irrigation water quality assessment. Thus, the salinity hazard is considered as the highest priority factor (4), while the miscellaneous effect to sensitive crops as the lowest factor in IWQI assessment (1). The remained two groups, corresponding to infiltration and permeability hazard and specific ion toxicity have the weights of 3 and 2, respectively. Indeed, the IWQI is calculated as following [6]:

$$
I W Q I=\sum_{i=1}^{4} G_{i}
$$

Where $i$ is an incremental index and $G_{i}$ is the contribution of each one of the four considered groups. Each $G_{i}$ is calculated according to the equation [7]:

$$
G_{i}=\frac{w_{i}}{k} \sum r_{j}
$$


With $w_{i}$ as the weight of each group, $k$ is the number of parameters included in each group and $r_{j}$ is the rating of each parameter.

Although the weight factors could present some differences for different geographical settings, with distinct soil conditions and different crop patterns, it is considered that the relevance for each one could be used in regular agricultural patterns and as a general water quality assessment tool (Simsek and Gunduz 2007). The suitability of water for irrigation is indicated by a numerical value of IWQI index and the groundwater will be classified into three levels corresponding to: low (IWQI < 22), medium (IWQI: 22-37) and high (IWQI > 37) suitability for irrigation (Table 3).

\subsection{Fuzzy Logic}

The real quantitative questions are proposed to be resolved using mathematical methodologies, bellowing deterministic methods These methods are reinforced by classical logic, which uses crisp sets. However, the different environmental uncertainties are not statistical and enforce the possibility of probability (Harris 2000). These uncertainties could be minimized using fuzzy logic (Shwetank et al. 2019). Fuzzy Logic was firstly introduced by Zadeh (1965) as a tool to consider uncertainties in measured quantities or to deal with reasoning, which is imprecise rather than exact (Baghel and Sharma 2013). It is also called multi-valued logic, and is used to resolve multifaceted problems, corresponding to imprecise and vague data (Mujumdar and Sasikumar 2002). The functions of classical logic discriminate members and non-members of a set by assigning them crisp values such as 1 and 0 , or true and false, respectively. Otherwise, functions of fuzzy logic (membership functions) discriminate members and non-members of a set by assigning them degrees of membership. The degree of membership, corresponding to a value attributed to each element, indicates the 
membership score of the elements (Shwetank et al. 2019). So, this methodology confers a very appreciable flexibility and will be possible to consider inaccuracies and uncertainties.

The fuzzy logic is based on fuzzy set and the variable to be modeled is considered as a linguistic variable (Zadeh 1971), and is characterized by a quadruplet (X, T(x), U, F(x)), where $\mathrm{X}$ is the name of the variable (e.g., water flow, ion concentration), $\mathrm{T}(\mathrm{x})$ the set of corresponding linguistic values (labels) (e.g., Low, Medium, High), U is the physical domain associated with the considered variable. $\mathrm{F}(\mathrm{x})$ is a semantic function (membership function) that associates a fuzzy meaning to any set $\mathrm{T}(\mathrm{x})$ (Driankov et al. 1993, Nakoula 1997). In general, the construction of a fuzzy model follows the syntax: If (premise) Then (Conclusion). So, a fuzzy rule can be written as the form: If $\mathrm{X}$ is $\mathrm{A}$ Then $\mathrm{Y}$ is $\mathrm{B}$.

The modeling of an input/output system by fuzzy logic is carried out in three essential phases: allow to model the system inputs as a curve function - membership functions (MFs) - and to delimit the fuzzy sets, which could have different shapes (e.g., triangular, trapezoidal) (Bouchon-Meunier 1995). Trapezoidal MFs were adopted as in other several studies (e.g., Jaiswal and Ballal 2020; Kosko, 1993; Shwetank et al. 2019), and could be written according to the equation:

$$
f(x, a, b, c, d)= \begin{cases}0 & x<a \text { or } d<x \\ \frac{a-x}{a-b} & a \leq x \leq b \\ 1 & b \leq x \leq c \\ \frac{d-x}{d-c} & c \leq x \leq d\end{cases}
$$

Where $\mathrm{x}$ is the variable to be fuzzified, $\mathrm{a}, \mathrm{b}, \mathrm{c}$ and $\mathrm{d}$ are the linguistic variables used to divide the parameters into classes (Fig. 2).

(ii) Inference engine which produces fuzzy output resulting from fuzzy input using fuzzy rules. At the presentation of each input, according to the fuzzy inference rules, the degree of 
belonging to a given subset is determined. These rules are constructed using logic operator such as AND to support minimum, OR to support maximum and NOT to support without.

(iii) Defuzzification, which is the last step, transforms the fuzzy set resulting from the inference into a numerical output value (crisp), and can be performed by several methods such as centroid, bisector, middle or maximum. The center of gravity technique or centroid defuzzification is applied in this research.

The Fuzzy Inference System (FIS) is developed using fuzzy logic toolbox of MATLAB software to classify groundwater for irrigation using Mamdani approach. The structure of the proposed fuzzy model is shown in Fig 3. The inputs are the different traditional irrigation water indices - EC, SAR, SSP, MAR, PI, KR - and the output will be the fuzzy irrigation water quality index - FIWQI -.

\section{Results and discussions}

\subsection{Groundwater geochemistry and water quality indices}

The minimum, maximum, average, and standard deviation of Menzel Habib aquifer groundwater physio-chemical parameters is presented in Table 4. Indeed, the concentration of chemical elements vary from: 879 to $2876.4 \mathrm{mg} / \mathrm{L}$ for $\mathrm{SO}_{4}, 489.6$ to $3265 \mathrm{mg} / \mathrm{L}$ for $\mathrm{Cl}, 318.6$ to $2064.6 \mathrm{mg} / \mathrm{L}$ for $\mathrm{Na}, 176.3$ to $894.7 \mathrm{mg} / \mathrm{L}$ for $\mathrm{Ca}, 109.9$ to $341.6 \mathrm{mg} / \mathrm{L}$ for $\mathrm{Mg}, 66.6$ to $188.6 \mathrm{mg} / \mathrm{L}$ for $\mathrm{HCO}_{3}$ and 18.27 to $53.01 \mathrm{mg} / \mathrm{L}$ for $\mathrm{K}$. However, the water content in $\mathrm{Br}$ and $\mathrm{F}$ is very low. Thus, a spatial variation is observed for the samples. The abundance of groundwater major ions has the following order: $\mathrm{SO}_{4}>\mathrm{Cl}>\mathrm{HCO}_{3}>\mathrm{Br}>\mathrm{F}$ for anions, and $\mathrm{Na}>\mathrm{Ca}>\mathrm{Mg}>\mathrm{K}$ for cations (Fig. 4).

The origin of major ions may be detected by different saturation indices of different minerals as a function of the ionic strength (Fig. 5). Thus, the saturation indices for halite, gypsum and 
anhydrite are negative (Fig. 5a, Fig. 5b., Fig. 5c). However, they are positive for calcite and dolomite (Fig. 5d, Fig. 5f). Indeed, the dissolution of evaporites, dissolution/precipitation of carbonates constitute the main sources of major elements (Bahir et al. 2018; Mejri et al. 2018; Sunkari et al. 2021). Some points are characterized by a release of $\mathrm{Ca}$ and adsorption of $\mathrm{Na}$, while others are characterized by release of $\mathrm{Na}$ and adsorption of $\mathrm{Ca}$ (Fig. 5f). This variability suggests that cationic exchange and inverse cationic exchange with soil and aquifer materials could be the main source of major ions (Abid et al. 2009; Kammoun et al. 2018).

The combination of the ions and physical parameters will promote the calculation of different water quality indices. These indices are classified into 4 classes: excellent, good, permissible, and unsuitable.

The SAR groundwater quality parameter from Menzel Habib groundwater varies from 4.08 to 19.3 which reflect that $36 \%$ of groundwater samples have an excellent quality and $64 \%$ with a good quality. The SSP groundwater parameter is an important parameter to assess the suitability of water to irrigation where an excess of sodium can affect the growth of plant. In the present study, the values are between $35.78 \%$ and $71.53 \%$. Additionally, the SSP allows to detect that $17 \%$ of the samples are of good quality, and $83 \%$ are permissible and, consequently, deemed for irrigation.

The KR groundwater quality parameter varies from 0.56 to 2.47 (Table 4), allowing that 25\% of groundwater samples have an excellent quality, $11 \%$ are of good quality and, $14 \%$ permissible. Otherwise, $50 \%$ of groundwater samples are unsuitable for irrigation purposes. The obtained results indicate that Menzel Habib groundwater is polluted by alkali hazard, according to defined criteria (Karanth 1987).

Indeed, the groundwater quality indices - SAR, KR, and SSP - may assess the deteriorating effect of $\mathrm{Na}$ contents in water and suggest that groundwater water from Menzel Habib aquifer 
is unsuitable for irrigation purposes. Additionally, the $\mathrm{Ca}$ concentration is lower than $\mathrm{Na}$ concentration for almost groundwater samples. Consequently, it doesn't counter the dispersing effect of water sodium content (Fig. 5f) and thus enhancing the cationic exchange and the inverse cationic exchange (Tanvir Rahman et al. 2017).

The PI groundwater quality parameter indicates the suitability of groundwater for irrigation purposes. The soil permeability is affected by soil sodium, calcium, magnesium, and bicarbonate contents. PI values from Menzel Habib groundwater range between $38.47 \%$ and $72.74 \%$ (Table 4). As a result, two water classes are detected: $64 \%$ of the samples are considered of good quality and $36 \%$ are permissible for irrigation purposes.

The MAR water quality indices is also used to characterize groundwater quality for irrigation concerning the excess of magnesium over calcium water content. The obtained values from Menzel Habib groundwater fall in the range of $34.19 \%$ to $56.01 \%$ (Table 4). The use of MAR water quality parameter allows to classify $92 \%$ of the samples which were belonged to the category of suitable for irrigation (MAR < 50\%). However, $8 \%$ of the groundwater samples obtained scores exceeding the allowed standard (MAR > 50\%) resulting in deleterious impacts upon crop yield and increased soil alkalinity. The continuous application of these water sources will pose adverse risks, requiring interventional strategies to be in satisfactory conditions (Paliwal, 1972). Furthermore, Ca and Mg ions are incapable of identical behavior in soil systems, whereby $\mathrm{Mg}$ will negatively impact soil structure in highly saline and predominantly sodium-dense water. Generally, high $\mathrm{Mg}$ water contents will result in a highly exchangeable $\mathrm{Na}$ (Fig. 5f) in the irrigated soils (FAO 2008). This situation could adversely affect soil quality and lead to poor agricultural yield.

Otherwise, SAR parameter can be combined with EC under USSL (United States Salinity Laboratory) classification in diagram of Richards (Fig. 6). This classification considers a low $(\mathrm{EC}<250 \mu \mathrm{S} / \mathrm{cm})$, moderate $(250<\mathrm{EC}<750 \mu \mathrm{S} / \mathrm{cm})$, high $(750<\mathrm{EC}<2250 \mu \mathrm{S} / \mathrm{cm})$, very 
high $(2250<\mathrm{EC}<5000 \mu \mathrm{S} / \mathrm{cm})$ and extremely high $(\mathrm{EC}>5000 \mu \mathrm{S} / \mathrm{cm})$ water salinity values assigned to the classes $\mathrm{C} 1, \mathrm{C} 2, \mathrm{C} 3, \mathrm{C} 4$ and $\mathrm{C} 5$, respectively. While S1, S2 and S3 fields are considered according to SAR classes as low, medium, and high, respectively. Groundwater from Menzel Habib aquifer system is distributed as three groundwater samples in C4S2, nine are classified as $\mathrm{C} 5 \mathrm{~S} 2$, one as $\mathrm{C} 4 \mathrm{~S} 3$, five as $\mathrm{C} 5 \mathrm{~S} 3$ and the other ones contain a SAR ratio higher than 10, with an extremely high salinity (Fig. 6). According to the obtained results, most groundwater samples from Menzel Habib should not be used under normal conditions (e.g., without drainage network, plant non-tolerant for salinity; Ayers and Westcot 1994; FAO 1997), however, could be applied in areas with permeable soil and containing tolerant salinity crops. The other groundwater samples, with EC > $10000 \mu \mathrm{S} / \mathrm{cm}$ and $\mathrm{SAR}>10$, are considered as harmful for irrigation purpose.

\subsection{IWQI assessment}

The four hazard groups are determined and combined to calculate IWQI and then to assess the groundwater quality irrigation purposes according to Equation 6. The IWQI index will consider three classes of groundwater suitability for irrigation purposes as: low (IWQI < 22), moderate $(22<\mathrm{IWQI}<37)$ and high suitability $(\mathrm{IWQI}>37)$.

Groundwater samples from Menzel Habib aquifer system present a calculated IWQI lower than 22, and, consequently, are included in a low suitability category. The application of groundwater from the aquifer system on irrigation purpose requires a prior treatment considering some restriction and adequate caution. The low groundwater quality could be associated to the high groundwater EC values as a consequence of a high groundwater salinity. As a result, a low rating is attributed for the groundwater salinity hazard group. Otherwise, groundwater samples also present a high sodium and chloride contents which 
could affect soil structure and permeability, as well as plants nutrition. Sodium and chloride water contents are relevant to the soil permeability assessment and to the infiltration hazard and specific ion toxicity relatively to groundwater quality. Indeed, these groundwater samples with high sodium and chloride concentration obtain a low score and are assigned by low ratings for the infiltration and permeability hazards and salinity hazard groups.

\subsection{Irrigation water quality index by fuzzy logic}

Considering groundwater quality indices obtained from Menzel Habib aquifer system will be crucial to attend adequate decisions on groundwater management of this region. Then, there is an overlap and ambiguity in making the decision regarding water quality for some samples. More precisely, on the area, there are some groundwater samples with values on the range limits, which could correspond to a more than one decision regarding to groundwater quality irrigation purposes. Hence, the suitability of Menzel Habib groundwater for irrigation was developed using fuzzy logic methodologies.

The groundwater quality indices, such as SAR, EC, SSP, MAR, PI, and KR, are considered as the inputs. The inputs are represented and resulted membership functions are constructed (Fig. 7). The resulted FIWQI has a score ranging between 0 and 1 (Fig. 8) and represents the output of defuzzification result for the studied groundwater samples.

Further, fuzzy logic has clearly improved groundwater classification by considering new water quality classes (Excellent to good, good to permissible, permissible to unsuitable) (Table 6) compared with the classification generated by the Richards diagram and IWQI adapted from Simsek and Gunduz method. As a result, 3\% of groundwater samples from Menzel Habib system are classified as "good quality", 3\% as "good to permissible quality", and $33 \%$ as "permissible quality" for irrigation purposes. About, $36 \%$ of total groundwater 
samples are classified as "permissible to unsuitable quality" for irrigation, while $25 \%$ are with an "unsuitable quality". The developed fuzzy index superiority over the diagram of Richards classification and the IWQI is particularly relevant in groundwater samples of similar quality, promoting a more consistent decision, particularly on groundwater samples with threshold values between two different classes. Overall, under USSL classification and the IWQI, the decision-making was based on crisp values, while the FIS drew flexible boundaries using linguistic terms with respect to threshold values between two different groundwater quality classes, thus allowing for more reliable information about groundwater quality.

\section{Conclusion}

The classification of groundwater quality for irrigation purposes applying combined conventional water quality indices and the method of Simsek and Gunduz has been improved on the Menzel Habib aquifer system, considering a groundwater distribution into different quality classes according to water composition and features. The IWQI calculated to groundwater from Menzel Habib aquifer suggests a low suitability for irrigation purposes.

A Fuzzy Inference System index (FIS) is proposed considering the incorporation of conventional water quality indices in a global one. The developed model has been validated with satisfactory results on groundwater samples for Menzel Habib aquifer system. The obtained FIS system is more adequate to Menzel Habib aquifer area than USSL system, or the conventional water quality indices and proposed Irrigation Water Quality Index. Thus, the FIS result will be more relevant on the groundwater classification for irrigation purpose. Furthermore, this methodology will avoid the uncertainties associated in decision making by adding new sub-classes (excellent to good, good to permissible, permissible to unsuitable). 


\section{Acknowledgments}

378 The authors are grateful to the staff of Applied Hydrosciences Laboratory for their effort and 379 support during laboratory anlysis. This research was developed under the FCT - Fundação 380 para a Ciência e a Tecnologia, I.P. program, through the project's reference 381 UIDB/04683/2020 and UIDP/04683/2020.

\section{Data availability}

Geochemical data were generated at the Applied Hydrosciences Laboratory, Higher Institute of Water Sciences and Techniques of Gabès, Tunisia. Derived data supporting the findings of this study are available from the corresponding author on request.

\section{References}

Abd El-Aziz, SH (2017) Evaluation of groundwater quality for drinking and irrigation purposes in the north-western area of Libya (Aligeelat). Environ Earth Sci 76, 147. https://doi.org/10.1007/s12665-017-6421-3

392

Abid K, Trabelsi R, Zouari K, Abidi B (2009) Caractérisation hydrogéochimique de la nappe du Continental Intercalaire (sud tunisien) / Hydrogeochemical characterization of the Continental Intercalaire aquifer (southern Tunisia). Hydrological Sciences Journal 54/3, 526-537. https://doi.org/10.1623/hysj.54.3.526

Agoubi B, Dabbaghi R, Kharroubi A (2018) A Mamdani Adaptive Neural Fuzzy Inference System for Improvement of Groundwater Vulnerability. Groundwater Journal 56/6, 978-985. 10.1111/gwat.12634 
Agoubi B, Kharroubi A, Abida H (2012) Saltwater intrusion modelling in Jorf coastal aquifer, South eastern Tunisia: Geochemical, geoelectrical and geostatistical application. Hydrol. Process. 27, 1191-1199. https://doi.org/10.1002/hyp.9207

Agoubi B, Souid F, Kharroubi A, Abdallaoui A (2016) Assessment of hot groundwater in an arid area in Tunisia using geochemical and fuzzy logic approaches. Environ Earth Sci. 75:1497. https://doi.org/10.1007/s12665-016-6296-8

Alabjah B, Amraoui F, Chibout M, Slimani M (2018) Assessment of saltwater contamination extent in the coastal aquifers of Chaouia (Morocco) using the electric recognition. J. Hydrol. 566, 363-376.

Al Maliki AA, Abbass ZD, Hussain HM, Al-Ansari N (2020) Assessment of the groundwater suitability for irrigation near Al Kufa City and preparing the final water quality maps using spatial distribution tools. Environ Earth Sci 79, 330. https://doi.org/10.1007/s12665-020-09060-w

Argamasilla M, Barberá JA, Andreo B (2017) Factors controlling groundwater salinization and hydrogeochemical processes in coastal aquifers from southern Spain. Sci. Total Environ. 580, 50-68. https://doi.org/10.1016/j.scitotenv.2016.11.173

Ayers R, Westcot D (1994) Food, Agriculture Organization of the United Nations (FAO), Water Quality for Agriculture, Irrigation and Drainage, Rome: Paper No. 29. Rev. 1, M-56. ISBN 92-5-102263-1.

Baghel A, Sharma T (2013) Survey on fuzzy expert system. International Journal of Emerging Technology and Advanced Engineering 3(12): 230-233.

Bahir M, Ouhamdouch S, Carreira PM (2018) Geochemical and isotopic approach to decrypt the groundwater salinization origin of coastal aquifers from semi-arid areas (Essaouira 
basin, Western Morocco). Environmental Earth Sciences, 77:485. https://doi.org/10.1007/s12665-018-7663-4

Ben Alaya M, Saidi S, Zemni T, Zargouni F (2013) Suitability assessment of deep groundwater for drinking and irrigation use in the Djeffara aquifers (Northern Gabes, south- eastern Tunisia). Environmental Earth Sciences 71(8). https://doi.org/10.1007/s12665-013-2729-9

Ben Cheikh N, Zouari K, Abidi B (2012) Geochemical and isotopic study of paleogroundwater salinization in southeastern Tunisia (Sfax bain). Quaternary International Journal 257: 34-42

Beyene G, Aberra D, Fufa F (2019) Evaluation of the suitability of groundwater for drinking and irrigation purposes in Jimma Zone of Oromia, Ethiopia. Groundwater for Sustainable Development 9, 100216. https://doi.org/10.1016/j.gsd.2019.100216

Bouchon-Meunier B (1995) La logique floue et ses applications, Addison-Wesley France, Paris, $257 \mathrm{p}$.

Burri NM, Weatherl R, Moeck C, Schirmer M (2019) A review of threats to groundwater quality in the anthropocene. Sci. Total Environ. 684, 136-154. https://doi.org/10.1016/j.scitotenv.2019.05.236

D'Alessandro W, Bellomo S, Brusca L, Kyriakopoulos K, Calabrese S, Daskalopoulou K (2017) The impact of natural and anthropogenic factors on groundwater quality in an active volcanic/geothermal system under semi-arid climatic conditions: The case study of Methana peninsula (Greece)

Driankov D, Hellendoom H, Reinfrank M (1993) An introduction to fuzzy control, SpringerVerlag, New York, États-Unis, 1993, 323 p. 
El Bilali A, Taleb A (2020) Prediction of irrigation water quality parameters using machine learning models in a semi-arid environment. Journal of the Saudi Society of Agricultural Sciences. 19, (7): 439-451. https://doi.org/10.1016/j.jssas.2020.08.001

FAO (Food and Agriculture Organization of the United Nations) (1997) La petite irrigation dans les zones arides: Principes et options

FAO (Food and Agriculture Organization of the United Nations) (2008) Irrigation in the Middle East Region in Figures. FAO, Rome

Ghazaryan K, Movsesyan HS, Gevorgyan A, Minkina T, Sushkova SN, Rajput VD, Mandzhieva SS (2020) Comparative hydrochemical assessment of groundwater quality from different aquifers for irrigation purposes using IWQI: A case-study from Masis province in Armenia. Groundwater for Sustainable Development 11, 100459. https://doi.org/10.1016/j.gsd.2020.100459

Harris J (2000) An Introduction to Fuzzy Logic Applications. International Series on Microprecessor-Based and Intelligent Systems Engineering. https://doi.org/10.1007/978-94-010-9042-1

Horton RK (1965) An index number system for rating water quality. J Water Pollut Control Fed 37(3):300-306

Hu KX, Awangea JL, Kuhna M, Saleema A (2019) Spatio-temporal groundwater variations associated with climatic and anthropogenic impacts in South-West Western Australia. Journal of Science of the Total Environment 696 (2019) 133599

Icaga Y (2007) Fuzzy evaluation of water quality classification. Ecol. Ind. 7:710-718

Isawi H, El-Sayed MH, Eissa M, Shouakar-Stash O, Shawky H, Abdel Mottaleb MS (2016) Integrated Geochemistry, Isotopes, and Geostatistical Techniques to Investigate 
Groundwater Sources and Salinization Origin in the Sharm EL-Shiekh Area, South Sinia, Egypt. Journal of Water, Air and Soil Pollution 227 :151. doi 10.1007/s11270016-2848-5

Jahin HS, Abuzaid AS, Abdellatif AD (2020) Using multivariate analysis to develop irrigation water quality index for surface water in Kafr El-Sheikh Governorate, Egypt. Environ. Technol. Innov. 17 https://doi.org/10.1016/j.eti.2019.100532.

Jaiswal S, Ballal MS (2020) Fuzzy inference based irrigation controller for agricultural demand side management. Journal of Computers and Electronics in Agriculture. https://doi.org/10.1016/j.compag.2020.105537

Jha MK, Shekhar A, Jenifer MA (2020) Assessing groundwater quality for drinking water supply using hybrid fuzzy-GIS-based water quality index. Water Research 179 (2020) 115867. https://doi.org/10.1016/j.watres.2020.115867

Kammoun S, Trabelsi R, Re V, Zouari K, Henchiri J (2018) Groundwater quality assessment in semi-arid regions using integrated approaches: the case of Grombalia aquifer (NE Tunisia). Environmental Monitoring and Assessment 190: 87. https://doi.org/10.1007/s10661-018-6469-x

Karanth KR (1987) Ground water assessment, development and management. Tata McGraw Hill Publishing Company Ltd., New Delhi, p720

Kavurmacı M, Karakuş CB (2020) Evaluation of Irrigation Water Quality by Data Envelopment Analysis and Analytic Hierarchy Process-Based Water Quality Indices: the Case of Aksaray City, Turkey. Water Air Soil Pollution, 231 :55. https://doi.org/10.1007/s11270-020-4427-z 
Kawo NS, Karuppannan S (2018) Groundwater quality assessment using water quality indexand GIS technique in Modjo River Basin, central Ethiopia. J. African Earth Sci. $147,300-311$

Kelley WP (1963) Use of saline irrigation water. Soil Science, 95, 355-391

Khan A, Umar R, Khan HH (2015) Hydrochemical characterization of groundwater in lower Kali watershed, Western UP, India. J Geol Soc India 86(2): 195-210

Kharroubi A, Telahigue F, Agoubi B, Azri C, Bouri S (2012) Hydrochemical and statistical studies of the groundwater salinization in Mediterranean arid zones: Case of the Jerba coastal aquifer in southeast Tunisia. Environ. Earth Sci. 67/7, 2089-2100. $10.1007 / \mathrm{s} 12665-012-1648-5$

Kopittke PM, So HB, Menzies NW (2006) Effect of ionic strength and clay mineralogy on $\mathrm{Na}-\mathrm{Ca}$ exchange and the SAR-ESP relationship. European Journal of Soil Science, 57, 626-633. https://doi.org/10.1111/j.1365-2389.2005.00753.x

Kosko B (1993) Fuzzy Thinking: The New Science of Fuzzy Logic. Hyperion, New York.

Li Z, Zhou B, Teng D, Yang W, Qiu D (2018) Comprehensive evaluation method of groundwater environment in a mining area based on fuzzy set theory. Geosystem Engineering 21(2), 103-112. https://doi.org/10.1080/12269328.2017.1386594

Lu H, Ma X (2020) Hybrid decision tree-based machine learning models for short-term water quality prediction.

Chemosphere

249, 126169. https://doi.org/10.1016/j.chemosphere.2020.126169

McKone TE, Deshpande AW (2005) Can fuzzy logic bring complex environmental problems into fucus? Environmental Science and Technology. 39 (2): 42A-47A. https://doi.org/10.1021/es0531632 
Mejri S, Chekirbene A, Tsujimura M, Boughdiri M, Mlayah A (2018) Tracing groundwater salinization processes in an inland aquifer: A hydrogeochemical and isotopic approach in Sminja aquifer (Zaghouan, northeast of Tunisia). Journal of Africain Earth Sciences 147, 511-522. https://doi.org/10.1016/j.jafrearsci.2018.07.009

Meyers G, Kapelan Z, Keedwell E (2017) Short-term forecasting of turbidity in trunk main networks. Water Res. 124, 67-76. https://doi.org/10.1016/j. watres.2017.07.035

Mirza ATM, Tanvir Rahman, Saadat AHM, Islam MdS, Al-Mansur MdA, Ahmed S (2017) Groundwater characterization and selection of suitable water type for irrigation in the western region of Bangladesh. Applied Water Sci. 7, 233-243. https://doi.org/10.1007/S13201-014- 0239-X

Mujumdar PP, Sasikumar K (2002) A fuzzy risk approach for seasonal water quality management of a river system. Water Resources Research 38(1):5-1. https://doi.org/10.1029/2000WR000126

Nadiri AA, Khatibi R, Vahedi F, Naderi K (2019) Spatial Prediction of Groundwater Level Using Models Based on Fuzzy Logic and Geostatistical Methods. GIS and Geostatistical Techniques for Groundwater Science. https://doi.org/10.1016/B978-0$\underline{12-815413-7.00007-9}$

Nadiri AA, Sedghi Z, Khatibi R, Gharekhani M (2017) Mapping vulnerability of multiple aquifers using multiple models and fuzzy logic to objectively derive model structures. Science of the Total Environment, 593-594 : 75-90

Nakoula Y (1997) Apprentissage des modèles linguistiques flous par jeu de règles pondérées. Thèse de Doctorat, Université de Savoie, 158 p 
Ostovari Y, Beigi-Harchegani H, Asgari K (2014) A fuzzy logic approach for assessment and mapping of groundwater irrigation quality: a case study of Marvdasht aquifer, Iran. Journal of Archives of Agronomy and Soil Science. http://dx.doi.org/10.1080/03650340.2014.946020

Paliwal KV (1972) Irrigation with saline water, 2 (New series. IARI monograph, New Delhi, p 198

Pathak DR, Bhandary NP (2020) Evaluation of groundwater vulnerability to nitrate in shallow aquifer using multi-layer fuzzy inference system within GIS environment. Groundwater for Sustainable Development $11 \quad$ (2020) 100470. https://doi.org/10.1016/j.gsd.2020.100470

Pazand K, Javanshir A (2014) Geochemistry andWater Quality Assessment of Groundwater Around Mohammad Abad Area, Bam District, SE Iran. Water Quality Exposure and Health. 6:225-231. https://doi.org/10.1007/s12403-014-0131-9

Prasad M, Sunitha V, Sudharsan Reddy Y, Suvarna B, Muralidhar Reddy B, Ramakrishna Reddy M (2019) Data on Water quality index development for groundwater quality assessment from Obulavaripalli Mandal, YSR district, Andhra Pradesh India. Data in Brief, 24, 10384610. https://doi.org/1016/j.dib.2019.103846

Raghunath HM (1990) Ground water. Wiley eastern limited (2nd ed.p. 563). New Delhi.

Rajaee T, Ebrahimi H, Nourani V (2019) A review of the artificial intelligence methods in groundwater level modeling. J. Hydrol. 572, 336-351. https://doi.org/ 10.1016/j.jhydrol.2018.12.037 
Rezaei F, Safavi HR, Ahmadi A (2013) Groundwater Vulnerability Assessment Using Fuzzy Logic: A Case Study in the Zayandehrood Aquifers, Iran. Environmental Management (2013) 51 :267-277. https://doi.org/10.1007/s00267-012-9960-0

Richards LA (1954) Diagnosis and improvement of saline and alkaline soils, US Salinity Laboratory, US Department of Agriculture Hand Book, pp 60.

Safiur Rahman M, Saha N, Islam ARMT, Shen S, Bodrud-Doza Md (2017) Evaluation of Water Quality for Sustainable Agriculture in Bangladesh. Journal of Water Air Soil Pollution 228, 385. https://doi.org/10.1007/s11270-017-3543-x

Schwarzenbach RP, Egli P, Hofstetter TB, von Gunten U, Wehrli B (2010) Annual Review of Environment and Resources 35 (1). https://doi.org/10.1146/annurev-environ-100809$\underline{125342}$

Shwetank, Suhas, Chaudhary JK (2019) Estimation of groundwater contamination using fuzzy logic: A case study of Haridwar, India. Journal of Groundwater for Sustainable Development. 8:644-653. https://doi.org/10.1016/j.gsd.2019.03.004

Simsek C, Gunduz O (2007) IWQ index: a GIS-integrated technique to assess irrigation water quality. Environmental Monitoring and Assessment, 128, 277-300.

Sunkari ED, Abu M, Zango MS (2021) Geochemical evolution and tracing of groundwater salinization using different ionic ratios, multivariate statistical and geochemical modeling approaches in a typical semi-arid basin. Journal of Contaminant Hydrology, 236, 103742. https://doi.org/10.1016/j.jconhyd.2020.103742

Sutadian AD, Muttil N, Yilmaz AG, Perera BJC (2017) Using the Analytic Hierarchy Process to identify parameter weights for developing a water quality index. Ecol. Indic. 75, 220-233. 
579 Tafreshi AM, Tafreshi GM, Keshavarzi MHB (2018) Qualitative zoning of groundwater to

580

581

582

583

584

585

586

587

588

589

590

591

592

593

594

595

596

597 assessment suitable drinking water using fuzzy logic spatial modelling via GIS. Water and Environment journal, 32: 607-620. https://doi.org/10.1111/wej.12358

Tanvir Rahman MATM, Saadat AHM, Islam MdS, Al-Mansur MdA, Ahmed S (2017) Groundwater characterization and selection of suitable water type for irrigation in the western region of Bangladesh. Applied Water Sci. 7, 233-243. https://doi.org/10.1007/S13201-014-0239-X

Telahigue F, Agoubi B, Souid F, Kharroubi A (2018) Assessment of seawater intrusion in an arid coastal aquifer, south-eastern Tunisia, using multivariate statistical analysis and chloride mass balance. Journal of Physics and Chemistry of the Earth.

Tian R, Wu J (2019) Groundwater quality appraisal by improved set pair analysis with game theory weightage and health risk estimation of contaminants for Xuecha drinking water source in a loess area in Northwest China. Hum Ecol Risk Assess 25(1-2):132157. https://doi.org/10.1080/10807039.2019.1573035

Tirupathi C, Shashidhar T, Pandey VP, Shrestha S (2019) Fuzzy- based approach for evaluating groundwater sustainability of Asian cities. Sustainable Cities and Society. https://doi.org/10.1016/j.scs.2018.09.027

Zadeh L (1965) Fuzzy sets. Inf. Contr., 8, 338-353

Zadeh L (1971) Quantitative fuzzy semantics, Inf. Sci., 3, 159-176. 


\section{Figures}

(a)

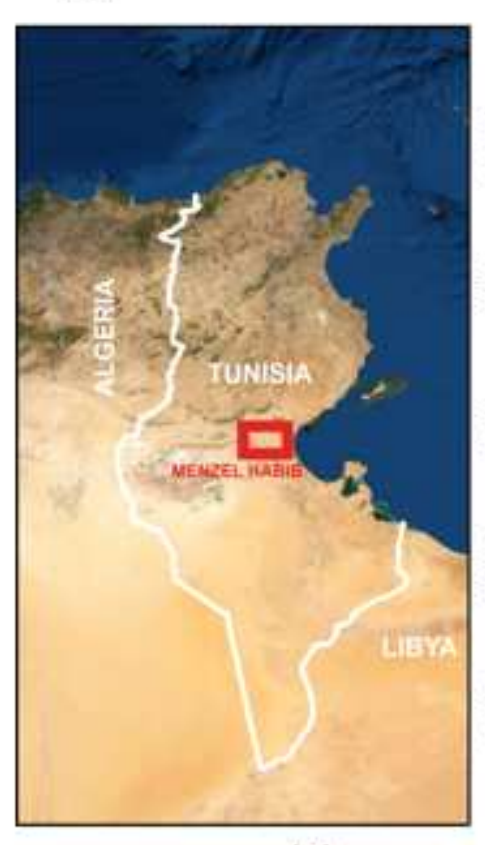

(c)

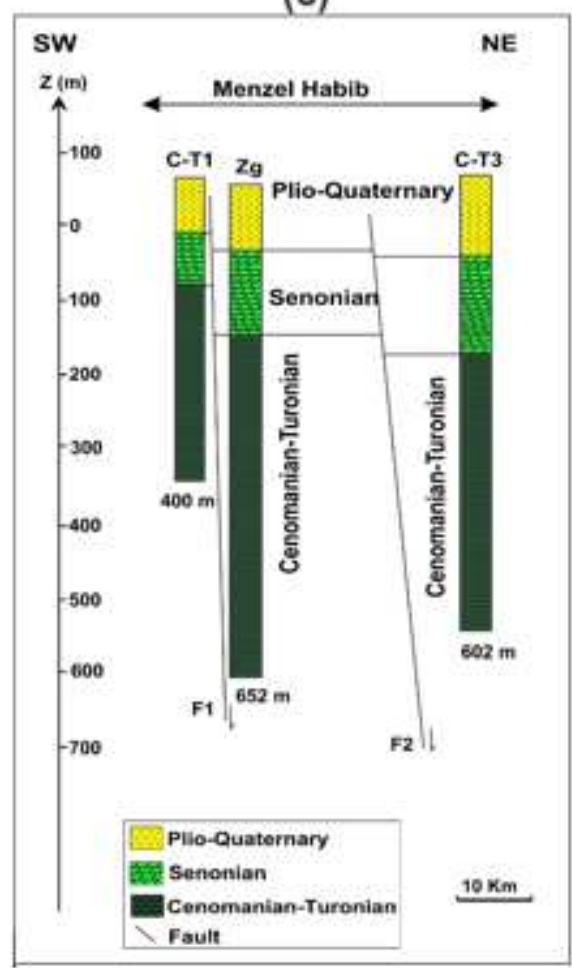

(b)

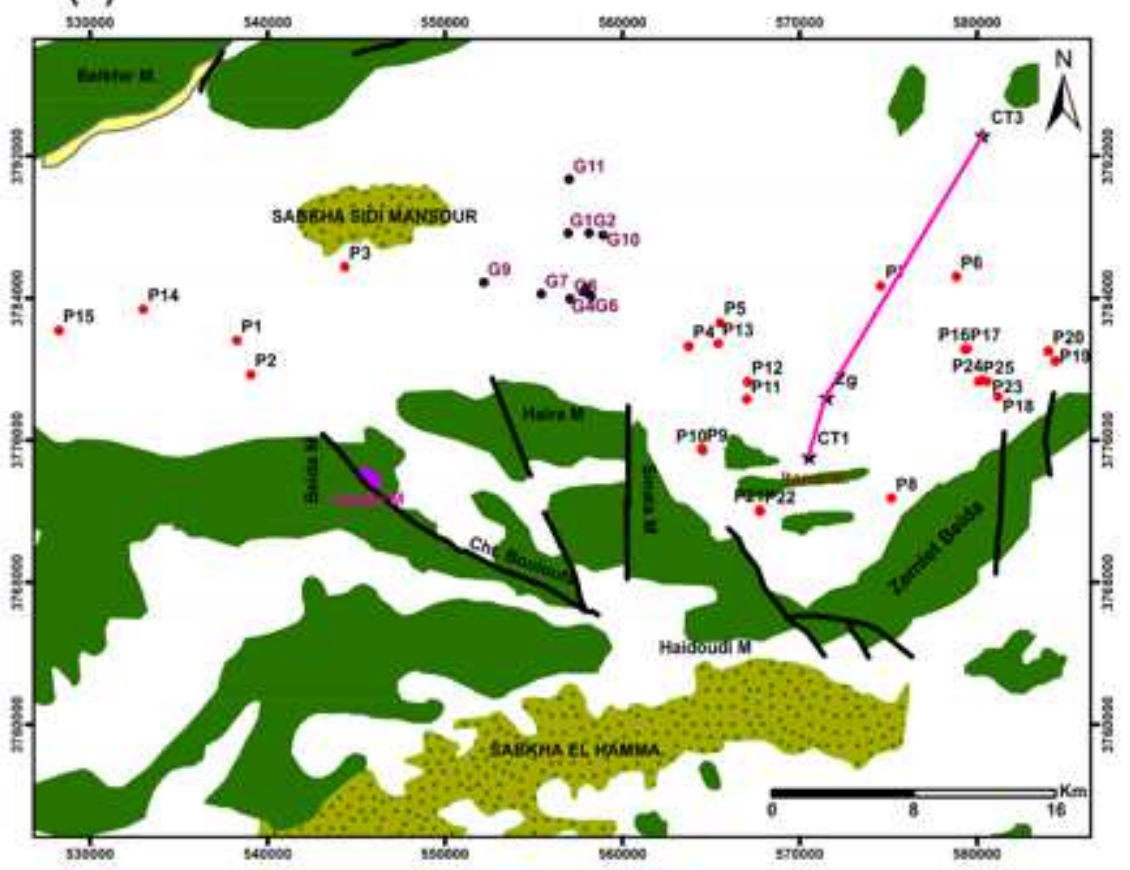

Legend

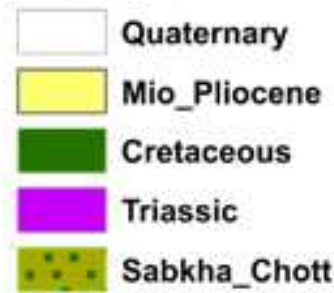

- Plio-Quaternary well

- Senonian borehole

$\star$ Borehole for cross section

Fault

Sabkha_Chott

\section{Figure 1}

Menzel Habib area: (a) Geographical location; (b) Simplified geological map of the aquifer system, including the spatial distribution of groundwater samples from Plio-quaternary well and Senonian borehole, and CT3-CT1 cross section; (c) Cross section from CT3-CT1 (Ben Cheikh et al. 2012) 


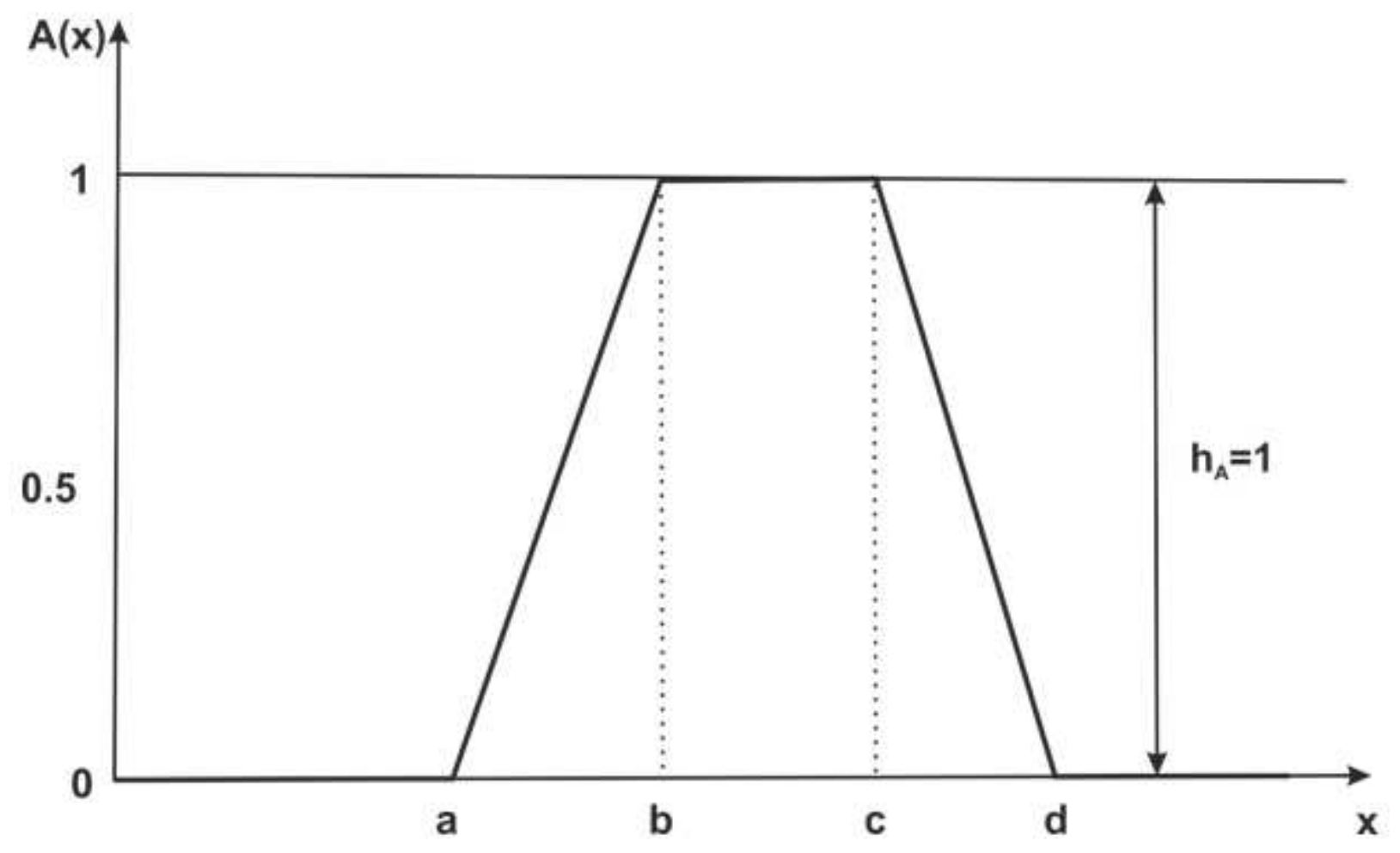

Figure 2

Illustration of trapezoidal of fuzzy membership function

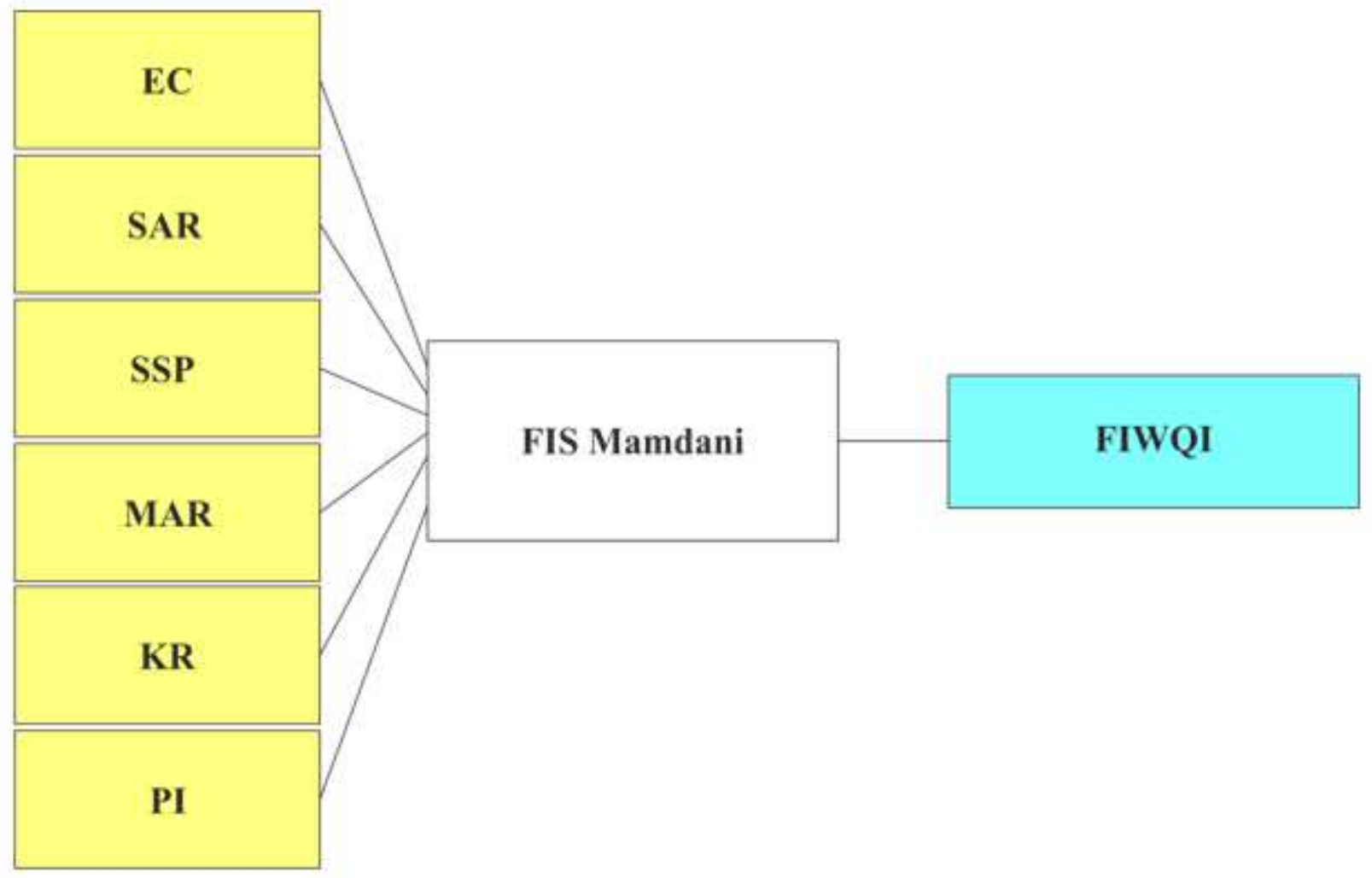

Figure 3 
Structure of fuzzy model

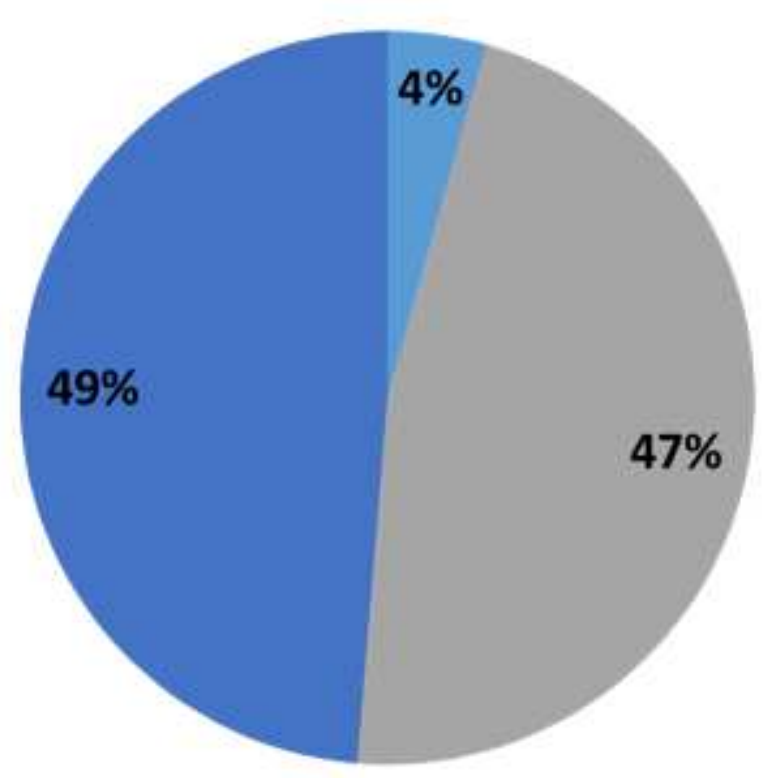

$=\mathrm{HCO}_{3}=\mathrm{Cl}=\mathrm{SO}_{4}$

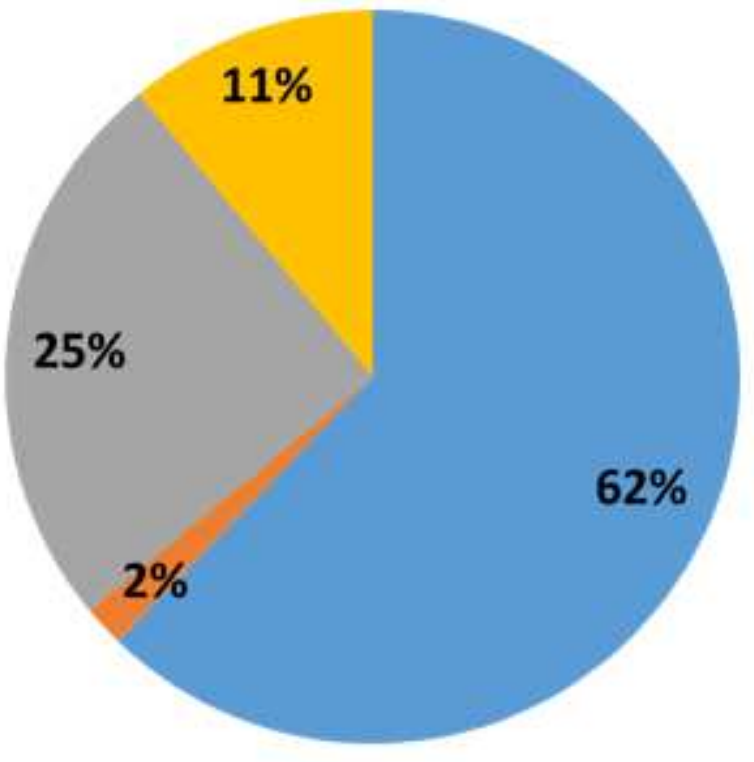

$=\mathrm{Na}=\mathrm{K}=\mathrm{Ca}=\mathrm{Mg}$

Figure 4

Groundwater samples plotted in Pie diagram 
(a)

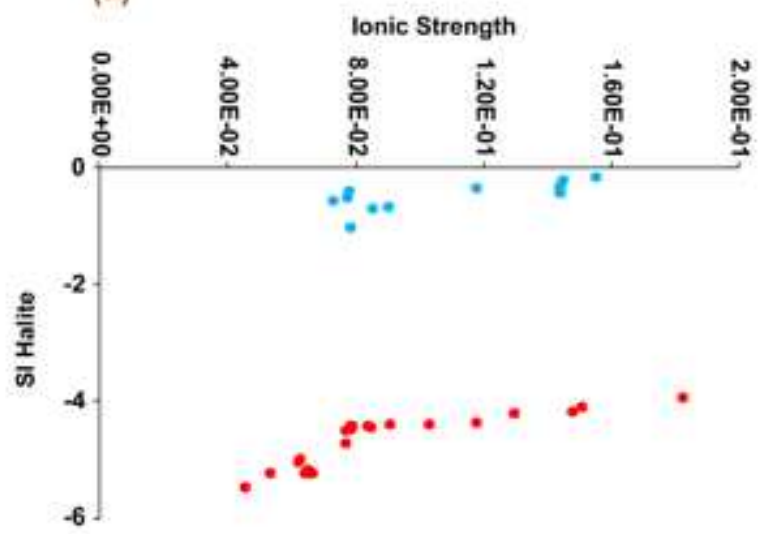

(c)
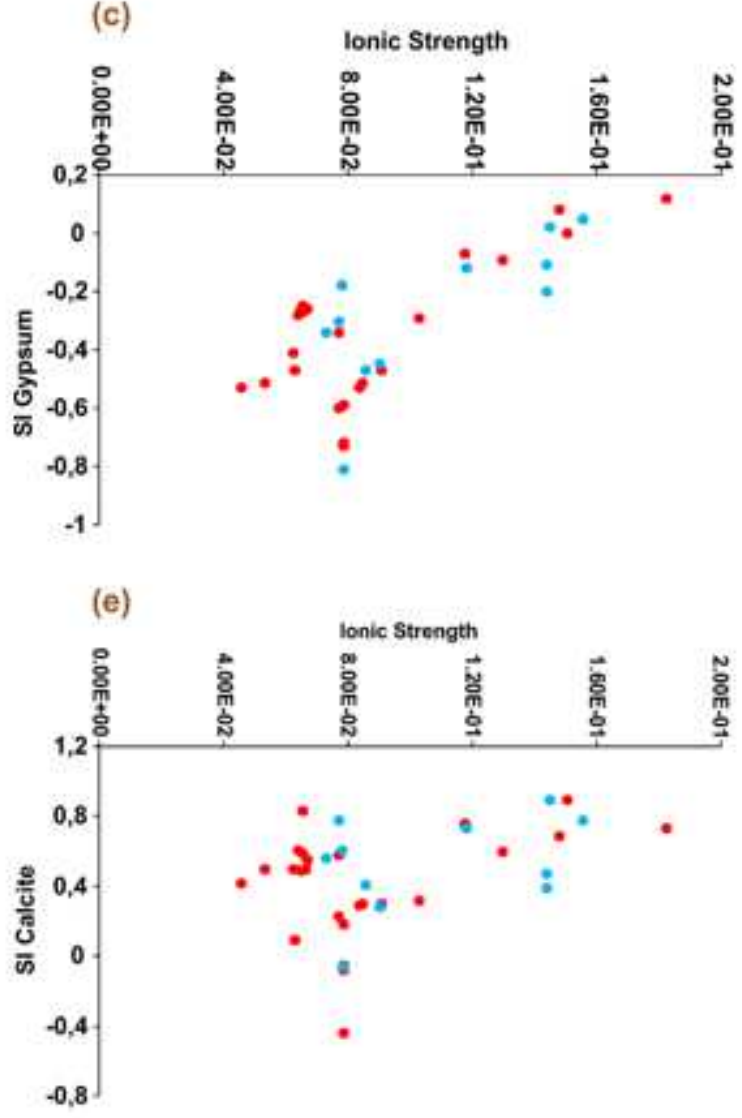

(b)

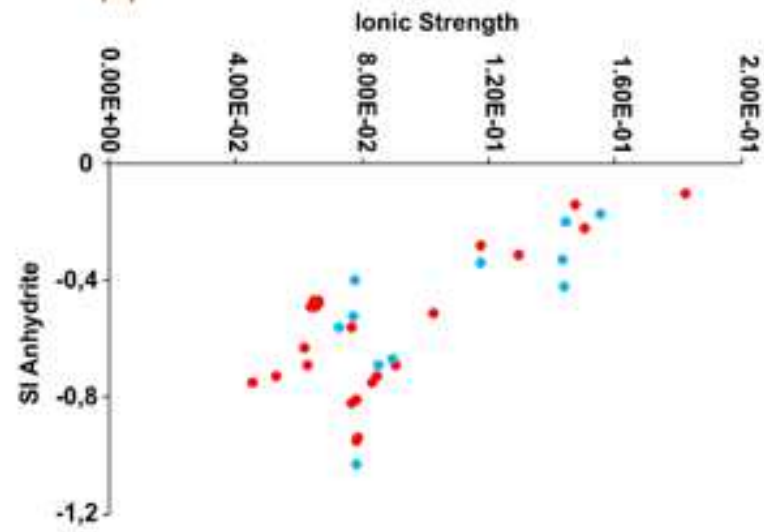

(d)

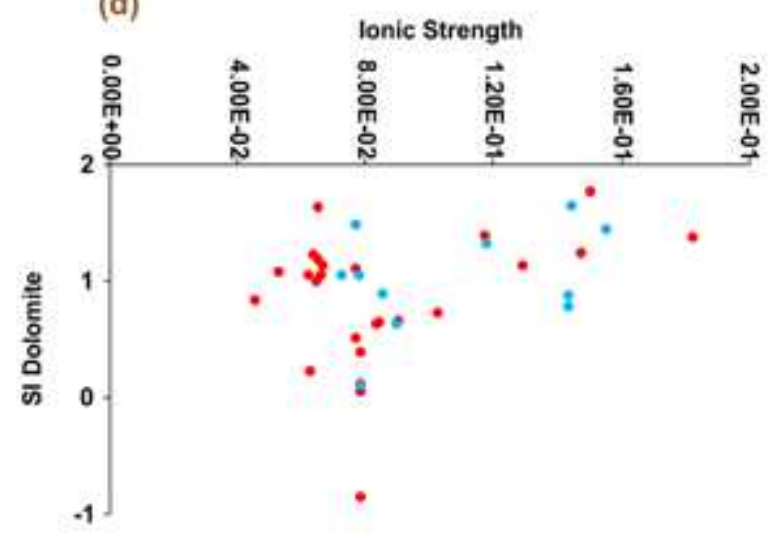

(f)

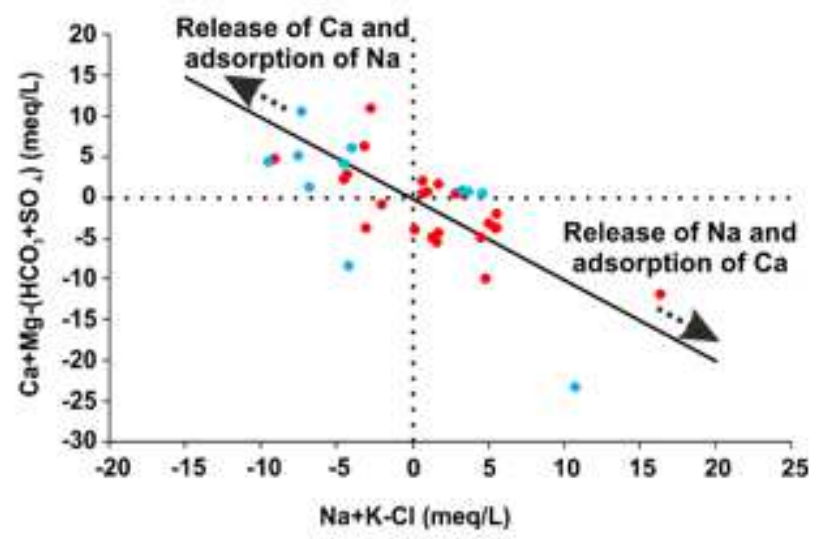

Figure 5

Ionic Strength versus: (a) Halite SI, (b) Anhydrite SI, (c) Gypsum SI, (d) Dolomite SI, (e) Calcite SI; (f) $\mathrm{Ca}+\mathrm{Mg}-(\mathrm{HCO}+\mathrm{SO} 4)$ versus $\mathrm{Na}+\mathrm{K}-\mathrm{Cl}$ 


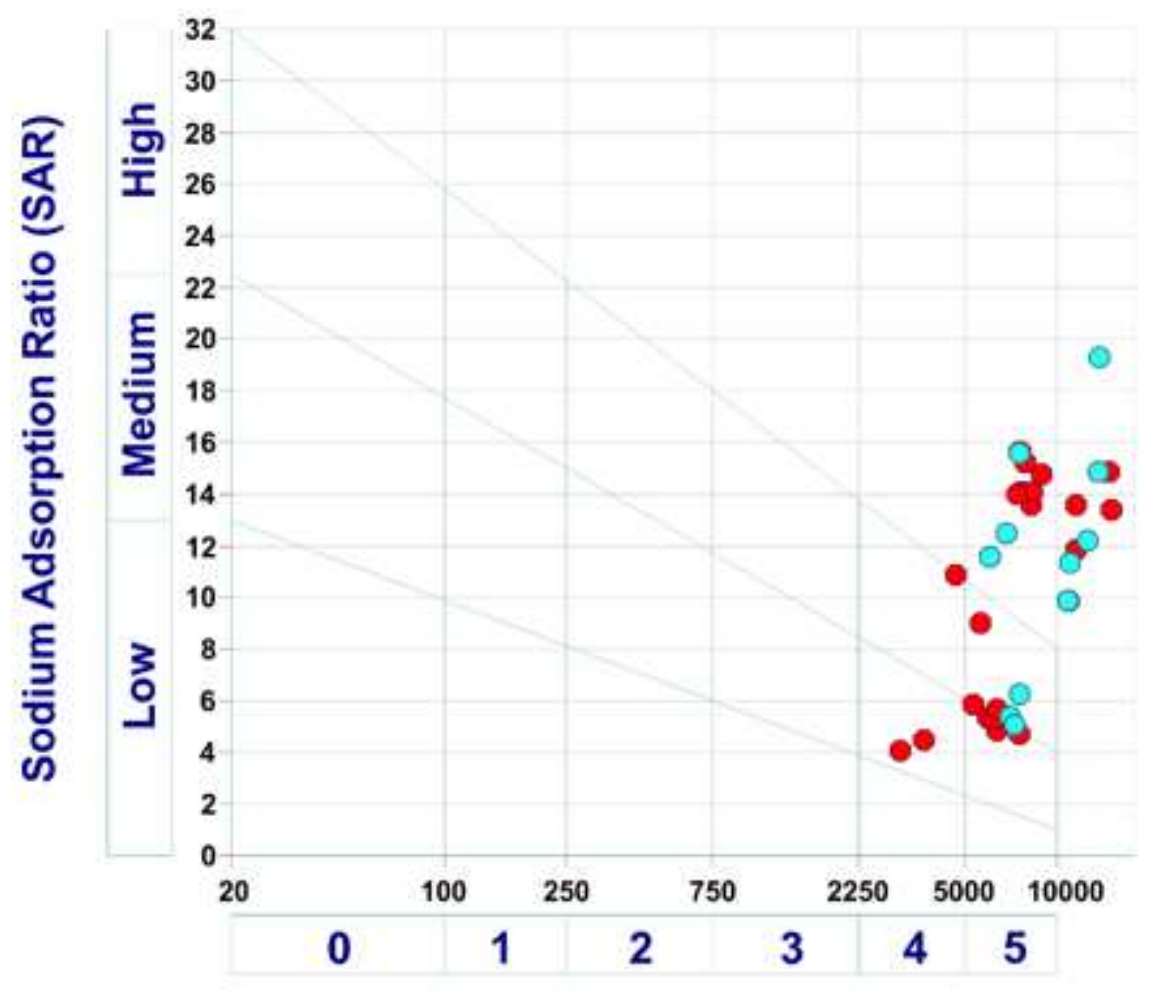

Electrical conductivity $(\mu \mathrm{S} / \mathrm{cm})$

- Sample from shallow aquifer

- Sample from deep aquifer

Figure 6

Groundwater samples plotted in Riverside diagram 
(a)

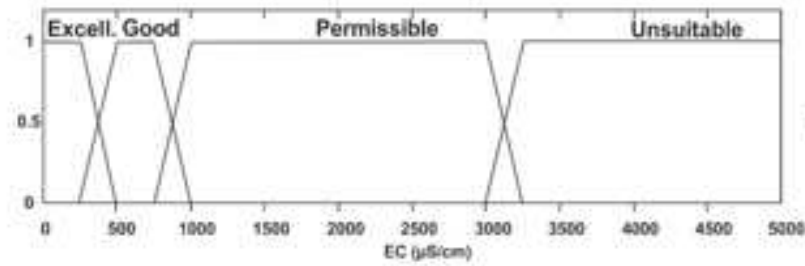

(c)

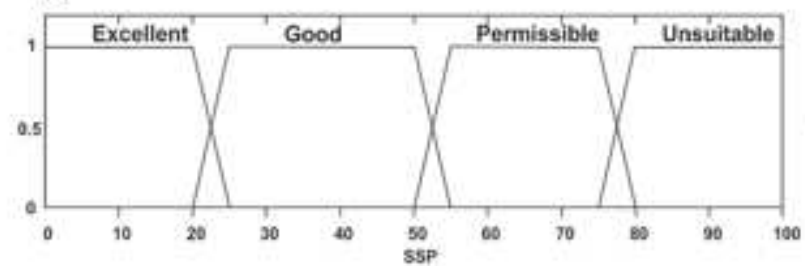

(c)

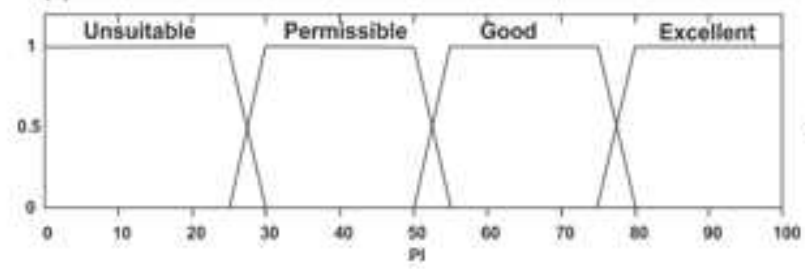

(b)

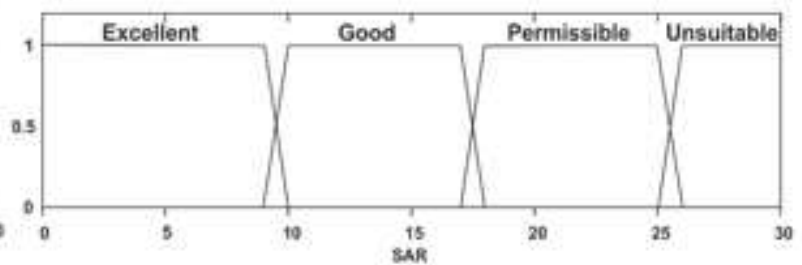

(d)

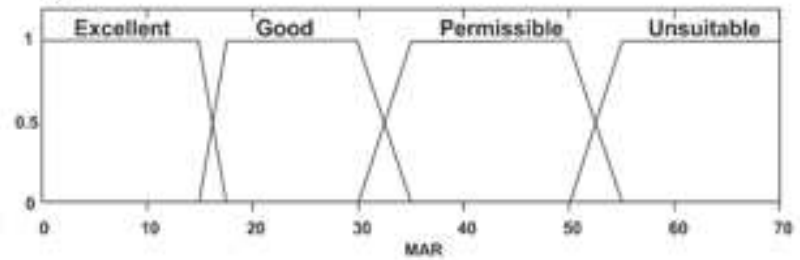

(i)

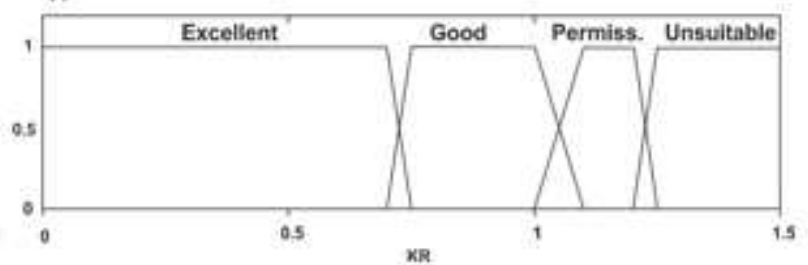

Figure 7

Inputs membership functions

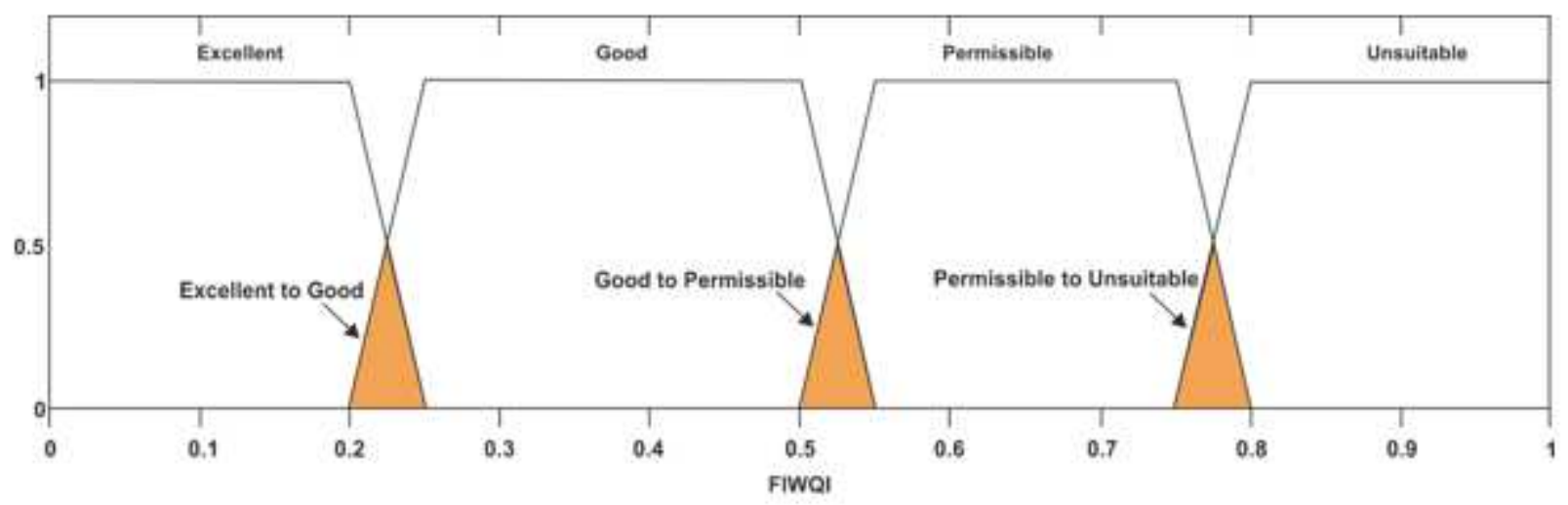

Figure 8

FIWQI classification of groundwater from Menzel Habib aquifer system 